\title{
EFFECTS OF MANAGEMENT PRACTICES ON GRASSLAND BIRDS:
}

\section{FERRUGINOUS HAWK}

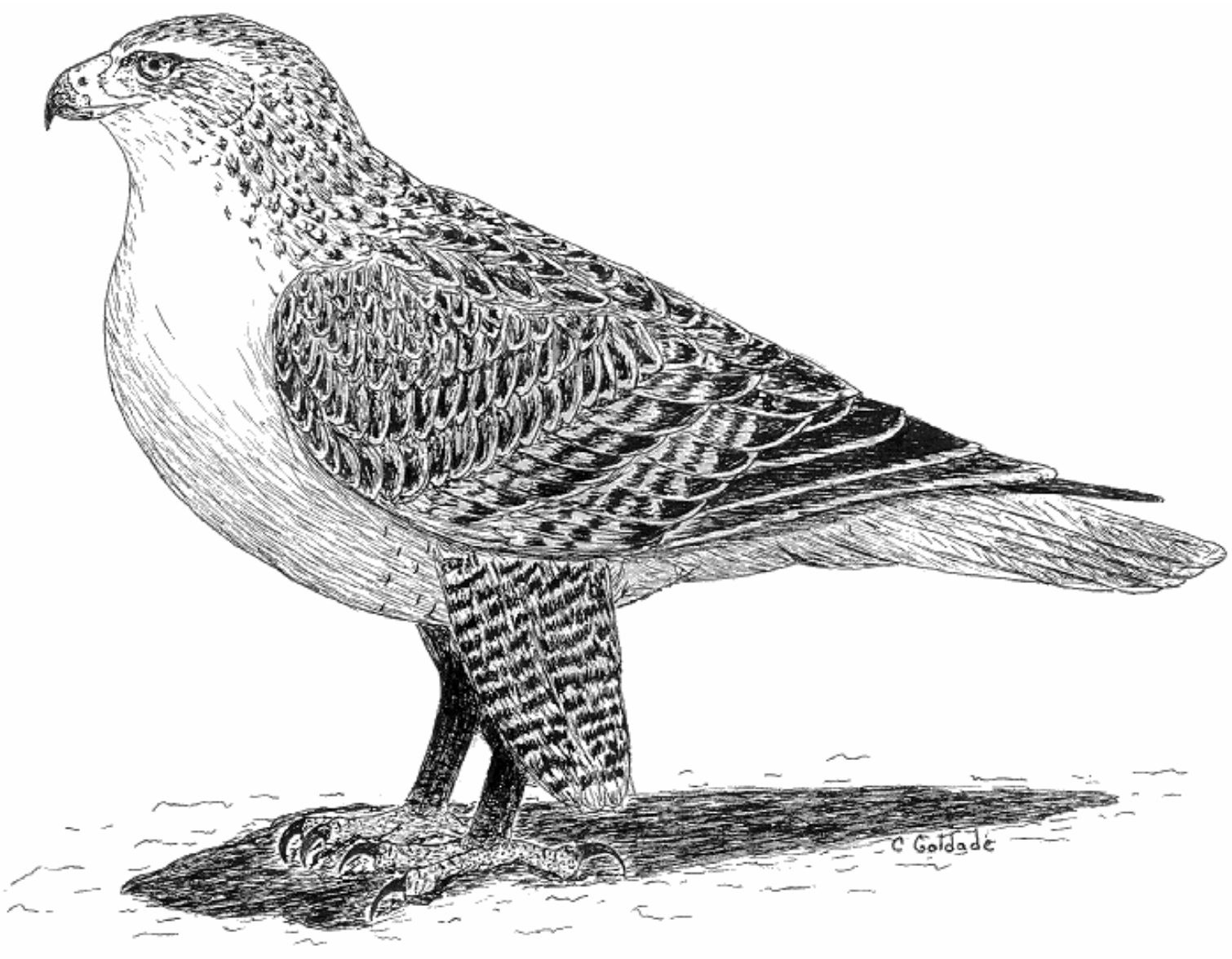

Grasslands Ecosystem Initiative

Northern Prairie Wildlife Research Center

U.S. Geological Survey

Jamestown, North Dakota 58401 
This report is one in a series of literature syntheses on North American grassland birds. The need for these reports was identified by the Prairie Pothole Joint Venture (PPJV), a part of the North American Waterfowl Management Plan. The PPJV recently adopted a new goal, to stabilize or increase populations of declining grassland- and wetland-associated wildlife species in the Prairie Pothole Region. To further that objective, it is essential to understand the habitat needs of birds other than waterfowl, and how management practices affect their habitats. The focus of these reports is on management of breeding habitat, particularly in the northern Great Plains.

Suggested citation:

Dechant, J. A., M. L. Sondreal, D. H. Johnson, L. D. Igl, C. M. Goldade, A. L. Zimmerman, and B. R. Euliss. 1999 (revised 2002). Effects of management practices on grassland birds: Ferruginous Hawk. Northern Prairie Wildlife Research Center, Jamestown, ND. 23 pages.

Species for which syntheses are available or are in preparation:

American Bittern

Mountain Plover

Marbled Godwit

Long-billed Curlew

Willet

Wilson's Phalarope

Upland Sandpiper

Greater Prairie-Chicken

Lesser Prairie-Chicken

Northern Harrier

Swainson's Hawk

Ferruginous Hawk

Short-eared Owl

Burrowing Owl

Horned Lark

Sedge Wren

Loggerhead Shrike

Sprague's Pipit
Grasshopper Sparrow

Baird's Sparrow

Henslow's Sparrow

Le Conte's Sparrow

Nelson's Sharp-tailed Sparrow

Vesper Sparrow

Savannah Sparrow

Lark Sparrow

Field Sparrow

Clay-colored Sparrow

Chestnut-collared Longspur

McCown's Longspur

Dickcissel

Lark Bunting

Bobolink

Eastern Meadowlark

Western Meadowlark

Brown-headed Cowbird 


\title{
EFFECTS OF MANAGEMENT PRACTICES ON GRASSLAND BIRDS:
}

\author{
FERRUGINOUS HAWK
}

Jill A. Dechant, Marriah L. Sondreal, Douglas H. Johnson, Lawrence D. Igl, Christopher M. Goldade, Amy L. Zimmerman, and Betty R. Euliss

Series Coordinator: Douglas H. Johnson Series Assistant Coordinator: Lawrence D. Igl

Reviewers: Loren W. Ayers, Joesph K. Schmutz, and Stephanie L. Jones

Range Map: Jeff T. Price

Cover Art: Christopher M. Goldade

Major Funding: Prairie Pothole Joint Venture, U.S. Fish and Wildlife Service U.S. Geological Survey

Funding also provided by: U.S. Forest Service The Nature Conservancy

\section{Collaborators:}

Louis B. Best, Iowa State University

Carl E. Bock, University of Colorado

Brenda C. Dale, Canadian Wildlife Service

Stephen K. Davis, Saskatchewan Wetland Conservation Corporation

James J. Dinsmore, Iowa State University

James K. Herkert, Illinois Endangered Species Protection Board

Fritz L. Knopf, Midcontinent Ecological Science Center

Rolf R. Koford, Iowa Cooperative Fish and Wildlife Research Unit

David R. C. Prescott, Alberta NAWMP Centre

Mark R. Ryan, University of Missouri

David W. Sample, Wisconsin Department of Natural Resources

David A. Swanson, Ohio Division of Wildlife

Peter D. Vickery, Massachusetts Audubon Society

John L. Zimmerman (retired), Kansas State University 


\section{ORGANIZATION AND FEATURES OF THIS SPECIES ACCOUNT}

Information on the habitat requirements and effects of habitat management on grassland birds were summarized from information in more than 4,000 published and unpublished papers. A range map is provided to indicate the relative densities of the species in North America, based on Breeding Bird Survey (BBS) data. Although birds frequently are observed outside the breeding range indicated, the maps are intended to show areas where managers might concentrate their attention. It may be ineffectual to manage habitat at a site for a species that rarely occurs in an area. The species account begins with a brief capsule statement, which provides the fundamental components or keys to management for the species. A section on breeding range outlines the current breeding distribution of the species in North America, including areas that could not be mapped using BBS data. The suitable habitat section describes the breeding habitat and occasionally microhabitat characteristics of the species, especially those habitats that occur in the Great Plains. Details on habitat and microhabitat requirements often provide clues to how a species will respond to a particular management practice. A table near the end of the account complements the section on suitable habitat, and lists the specific habitat characteristics for the species by individual studies. A special section on prey habitat is included for those predatory species that have more specific prey requirements. The area requirements section provides details on territory and home range sizes, minimum area requirements, and the effects of patch size, edges, and other landscape and habitat features on abundance and productivity. It may be futile to manage a small block of suitable habitat for a species that has minimum area requirements that are larger than the area being managed. The Brown-headed Cowbird (Molothrus ater) is an obligate brood parasite of many grassland birds. The section on cowbird brood parasitism summarizes rates of cowbird parasitism, host responses to parasitism, and factors that influence parasitism, such as nest concealment and host density. The impact of management depends, in part, upon a species' nesting phenology and biology. The section on breeding-season phenology and site fidelity includes details on spring arrival and fall departure for migratory populations in the Great Plains, peak breeding periods, the tendency to renest after nest failure or success, and the propensity to return to a previous breeding site. The duration and timing of breeding varies among regions and years. Species' response to management summarizes the current knowledge and major findings in the literature on the effects of different management practices on the species. The section on management recommendations complements the previous section and summarizes specific recommendations for habitat management provided in the literature. If management recommendations differ in different portions of the species' breeding range, recommendations are given separately by region. The literature cited contains references to published and unpublished literature on the management effects and habitat requirements of the species. This section is not meant to be a complete bibliography; a searchable, annotated bibliography of published and unpublished papers dealing with habitat needs of grassland birds and their responses to habitat management is posted at the Web site mentioned below.

This report has been downloaded from the Northern Prairie Wildlife Research Center WorldWide Web site, www.npwrc.usgs.gov/resource/literatr/grasbird/grasbird.htm. Please direct comments and suggestions to Douglas H. Johnson, Northern Prairie Wildlife Research Center, U.S. Geological Survey, 8711 37th Street SE, Jamestown, North Dakota 58401; telephone: 701253-5539; fax: 701-253-5553; e-mail: Douglas_H_Johnson@usgs.gov. 


\section{FERRUGINOUS HAWK}

(Buteo regalis)

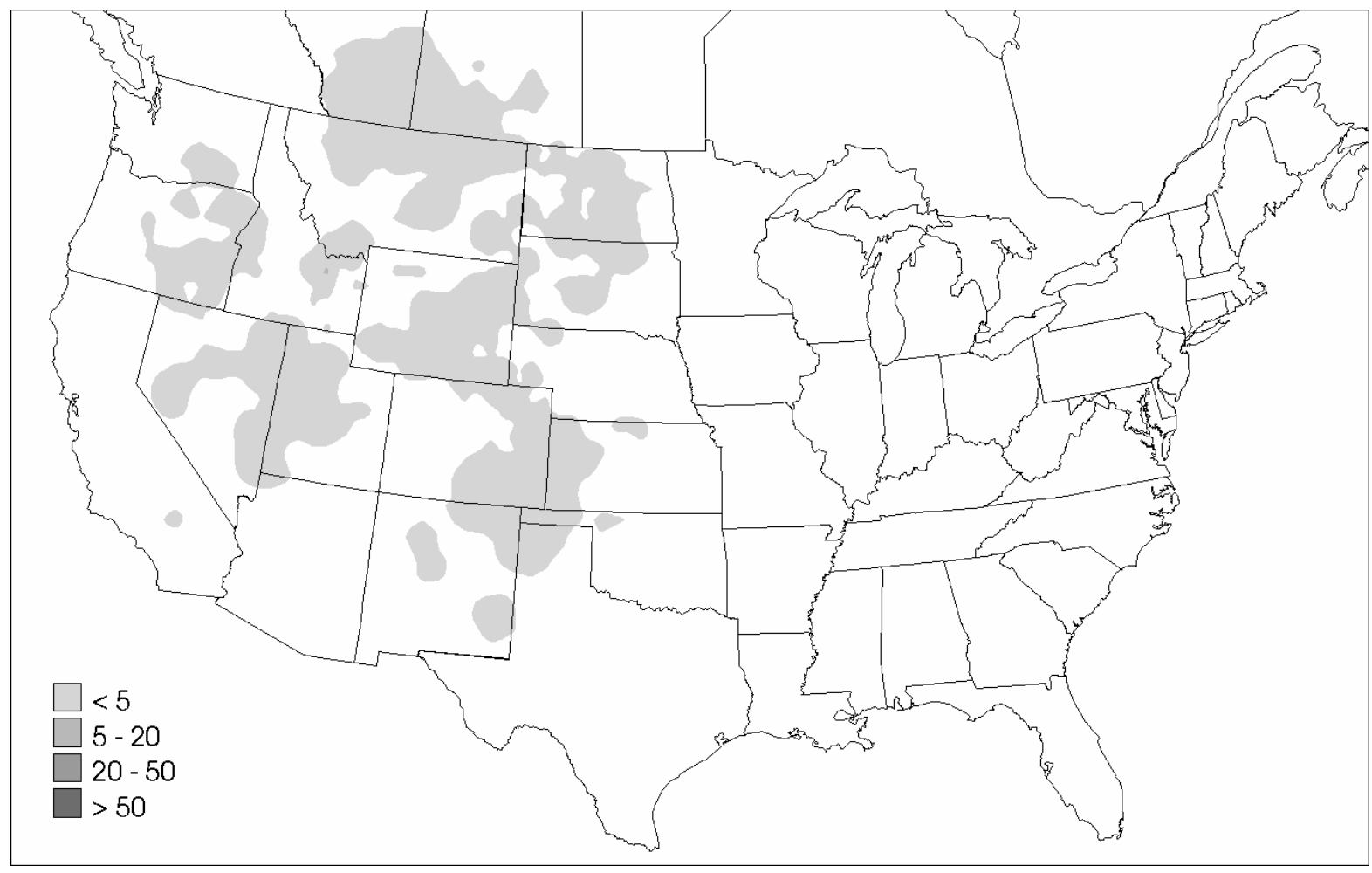

Figure. Breeding distribution of the Ferruginous Hawk in the United States and southern Canada, based on Breeding Bird Survey data, 1985-1991. Scale represents average number of individuals detected per route per year. Map from Price, J., S. Droege, and A. Price. 1995. The summer atlas of North American birds. Academic Press, London, England. 364 pages.

Keys to management are providing suitable nest sites, protecting active nest areas from disturbance, and improving habitat for prey.

\section{Breeding range:}

Ferruginous Hawks breed from northeastern Washington, southern Alberta and southern Saskatchewan, south to eastern Oregon, western Nevada, southern California, and northern Arizona, and east through northern Texas, western Oklahoma, and eastern North Dakota (National Geographic Society 1987). (See figure for the relative densities of Ferruginous Hawks in the United States and southern Canada, based on Breeding Bird Survey data.) Two subpopulations of Ferruginous Hawk are recognized (Bechard and Schmutz 1995). In this summary, "central" refers to the subpopulation east of the Rocky Mountains and "western" refers to the subpopulation west of the Rocky Mountains.

\section{Suitable habitat:}

Ferruginous Hawks prefer open grasslands and shrubsteppe communities. They use native and tame grasslands, pastures, hayland, cropland, and shrubsteppe (Stewart 1975, Woffinden 1975, Powers and Craig 1976, Fitzner et al. 1977, Blair 1978, Wakeley 1978, Lardy 1980, Schmidt 1981, Gilmer and Stewart 1983, Green and Morrison 1983, Konrad and Gilmer 
1986, MacLaren et al. 1988, Palmer 1988, Roth and Marzluff 1989, Bechard et al. 1990, Black 1992, Leslie 1992, Niemuth 1992, Bechard and Schmutz 1995, Faanes and Lingle 1995, Houston 1995, Zelenak and Rotella 1997, Leary et al. 1998). Ferruginous Hawks usually occupy rolling or rugged terrain (Blair 1978, Palmer 1988, Black 1992). High elevations, forest interiors, narrow canyons, and cliff areas are avoided (Janes 1985, Palmer 1988, Black 1992), as is parkland habitat in Canada (Schmutz 1991a).

Ferruginous Hawks are opportunistic nesters (Olendorff 1973, Woffinden 1975, Gilmer and Stewart 1983, MacLaren et al. 1988, Zelenak and Rotella 1997). Historically, the majority of nests were on or near the ground (dirt/rock/chalk outcrops, riverbed mounds, mud buttes, and rock piles); more recently, many nests are built in trees and large shrubs, on utility structures, artificial platforms, roofs of abandoned buildings, and river cutbanks (Davy 1930; Weston 1968; Olendorff 1973; Stewart 1975; Woffinden 1975; Lokemoen and Duebbert 1976; Fitzner et al. 1977; Blair 1978; Smith and Murphy 1978; Johnsgard 1979; Lardy 1980; Blair and Schitoskey 1982; Houston 1982, 1985; Gilmer and Stewart 1983; Woffinden and Murphy 1983; Ratcliffe and Murray 1984; Schmutz 1984, 1987, 1991a; Gaines 1985; MacLaren et al. 1988; Palmer 1988; Roth and Marzluff 1989; Bechard et al. 1990; De Smet and Conrad 1991; Atkinson 1992; Black 1992; Leslie 1992; Niemuth 1992; Bechard and Schmutz 1995; Faanes and Lingle 1995).

Landscapes with moderate coverages $(<50 \%)$ of cropland and hayland are used for nesting and foraging (Blair 1978; Wakeley 1978; Gilmer and Stewart 1983; Konrad and Gilmer 1986; Schmutz 1989, 1991a; Bechard et al. 1990; Faanes and Lingle 1995; Leary et al. 1998). In North Dakota, hayfields and native pastures were the habitats most often used by both fledglings and adults, whereas cultivated fields rarely were used (Konrad and Gilmer 1986). Fledglings in South Dakota hunted in an area where native hay recently had been cut (Blair 1978). When prey densities were low in big sagebrush (Artemisia tridentata) /grassland habitat, agricultural fields served as important foraging areas (Leary et al. 1998). Ferruginous Hawks foraged extensively in alfalfa (Medicago sativa) and irrigated potato fields in Washington and in alfalfa fields in Idaho during the breeding season presumably because of high prey densities (Wakeley 1978, Leary et al. 1998).

Nest site selection depends upon available substrates and surrounding land use. Ground nests typically are located far from human activities and on elevated landforms in large grassland areas (Lokemoen and Duebbert 1976, Blair 1978, Blair and Schitoskey 1982, Gilmer and Stewart 1983, Atkinson 1992, Black 1992). Lone or peripheral trees are preferred over densely wooded areas when trees are selected as the nesting substrate (Weston 1968, Rising 1974, Lokemoen and Duebbert 1976, Gilmer and Stewart 1983, Woffinden and Murphy 1983, Palmer 1988, Bechard et al. 1990, Leslie 1992, Hansen 1994). Tree-nesting hawks seem to be less sensitive to surrounding land use, but they still avoid areas of intensive agriculture or high human disturbance (Gilmer and 1983; Schmutz 1984, 1987, 1991a; Bechard et al. 1990, Hansen 1994). In Alberta, however, cultivated areas (11-30\% of 4,100-ha plots) had higher nesting densities than grassland areas with $0-11 \%$ cultivation (Schmutz 1989). In cultivated areas (20\%) in northcentral Montana, nests closer to cultivated fields and roads were more successful, presumably because of higher prey densities associated with edge habitats (Zelenak and Rotella 1997). The numbers of fledglings produced in unfragmented rangeland versus a mixture of rangeland and cropland were not significantly different in Nebraska (Podany 1996). In eastern Colorado, Ferruginous Hawks nested more frequently in grassland areas than in cultivated areas (Olendorff 1973, Leslie 1992). In North Dakota, Ferruginous Hawks preferred to nest in areas 
dominated by pasture and hayland (Gilmer and Stewart 1983, Gaines 1985). In southwestern Montana, sagebrush (Artemisia) and grasslands predominated within $100 \mathrm{~m}$ of nests (Atkinson 1992). Ground nests in northern Montana were located in grass-dominated, rolling ( $>10 \%$ slope) rangeland; in general, cropland and areas with dense (>30\% cover), tall $(>15.24 \mathrm{~cm})$ sagebrush were avoided (Black 1992). In western Kansas, most nests were surrounded by $\geq 50 \%$ rangeland and $25-50 \%$ cropland, although one pair incorporated $>75 \%$ cropland in its territory (Roth and Marzluff 1989). The majority of nests (86 of 99) were not in direct view of black-tailed prairie dog (Cynomys ludovicianus) towns, although most nest sites were within $8 \mathrm{~km}$ of towns (Roth and Marzluff 1989). In Utah, Idaho, Oregon, and California, Ferruginous Hawks preferred native grassland and shrubland habitats over cropland, and preferred areas with no perches (Janes 1985). In Washington, some nests occurred in agricultural fields, but most nests were in areas with higher percentages of grassland, shrubland, and western juniper (Juniperus occidentalis) (Bechard et al. 1990). Nest productivity in Idaho was greater in territories with higher amounts of crested wheatgrass (Agropyron cristatum) fields interspersed with desert shrub than in territories with monotypic stands of crested wheatgrass or shrubland, or with greater amounts of Utah juniper (Juniperus osteosperma), alfalfa, and cropland (Howard 1975).

The height, exposure, and slope of Ferruginous Hawk nests were mostly similar across the species’ range. In South Dakota, the mean height of buttes or hills on which ground nests were built was $<10 \mathrm{~m}$ above the surrounding prairie; nests were oriented toward the south and west, providing access to prevailing winds from the south and west (Blair 1978). Lokemoen and Duebbert (1976) found ground nests in South Dakota were all oriented toward the west. Nests in southwestern Montana were significantly oriented toward the south (Atkinson 1992). Nests on rock outcrops in Montana were built on slopes averaging 62.8\% and were found on the upper 35\% of the slope (Atkinson 1992). In North Dakota, most ground nests were on slopes near hillcrests or ridgetops (Johnsgard 1979). Ground nests in northern Montana were located either on the top of a small rise or on slopes ranging from 10 to 50\% (Black 1992). Average height of ground nests below the highest surrounding topographic feature was $10 \mathrm{~m}$, whereas average height of ground nest sites above the valley floor was $10.4 \mathrm{~m}$, indicating that nests were placed at mid-elevation sites within the immediate topography (Black 1992). Ferruginous Hawk nests in Wyoming were built on a mean slope of $14.26^{\circ}$, and the mean height of nests was $4.55 \mathrm{~m}$ (MacLaren et al. 1988). In North Dakota, mean nest height was 8 m (Johnsgard 1979). In eastern Colorado, the mean height of nesting trees was $10.3 \mathrm{~m}$ (Leslie 1992). In western Kansas, nests were placed on ledges 2-3 m high (Rising 1974). In Manitoba, high nests were more successful than low nests; of 59 nests $>8$ m high, 69\% were successful, compared to $58 \%$ of 57 nests 5-8 $\mathrm{m}$ high and $42 \%$ of 59 nests $<5 \mathrm{~m}$ high (De Smet 1992). In southeastern Washington, $86 \%$ of nests on outcrops and in western junipers were located $<10 \mathrm{~m}$ from the ground and had southern or western exposures (Bechard et al. 1990). In Oregon shrubsteppe, nests were in relatively short western juniper trees, were $<10 \mathrm{~m}$ from the ground, and had large support branches (Green and Morrison 1983). In Washington, Idaho, and Utah, the majority of nests also were $<10 \mathrm{~m}$ from the ground in western juniper and Utah juniper trees (Woffinden 1975, Fitzner et al. 1977, Woffinden and Murphy 1983, Hansen 1994). Howard (1975) and Howard and Wolfe (1976) also found Utah juniper trees were important nest substrates in southern Idaho and northern Utah. In Utah, nests were built 2-3 m from the ground, were most commonly located on the sides or summits of hills, and often had southern or eastern exposures (Weston 1968). 
Woffinden (1975) found that the majority of nests in Utah were on slopes ranging from 15 to $80^{\circ}$ with a mean of $42.5^{\circ}$.

Ferruginous Hawks are easily disturbed during the breeding season (Olendorff 1973, Gilmer and Stewart 1983, Schmutz 1984, White and Thurow 1985, Bechard et al. 1990, Leslie 1992, Hansen 1994). Abandonment of nests occurs particularly in the early stages of nesting (Davy 1930, Weston 1968, Fitzner et al. 1977, Gilmer and Stewart 1983, White and Thurow 1985). Sensitivity to disturbance may be heightened in years of low prey abundance (White and Thurow 1985). In eastern Colorado, nests in remote locations had greater productivity compared to more accessible nests (Olendorff 1973). In South Dakota, the probability of fledging young was $11.4 \%$ greater in more remote nests than in nests within $2.47 \mathrm{~km}$ of occupied buildings (Blair 1978). In North Dakota, Ferruginous Hawks avoided cropland and nesting within 0.7 km of occupied buildings (Gaines 1985). In Alberta, Ferruginous Hawks rarely nested within 0.5 $\mathrm{km}$ of farmyards (Schmutz 1984). In other instances, Ferruginous Hawks are more tolerant of human disturbance. Nesting has occurred near active railroads and gravel roads (Rolfe 1896, Gilmer and Stewart 1983, MacLaren et al. 1988). In Manitoba, 75\% of nests located using road surveys were within $0.8 \mathrm{~km}$ of roads or maintained trails (De Smet and Conrad 1991). A table near the end of the account lists the specific habitat characteristics for Ferruginous Hawks by study.

\section{Prey habitat:}

Ferruginous Hawk density and productivity are closely associated with cycles of prey abundance (Woffinden 1975; Powers and Craig 1976; Smith and Murphy 1978, Smith et al. 1981; Gilmer and Stewart 1983; Houston and Bechard 1984; White and Thurow 1985; Palmer 1988; Schmutz 1989, 1991a; Schmutz and Hungle 1989; Bechard and Schmutz 1995). Mammals are the primary prey during the breeding season, although birds, amphibians, reptiles, and insects also are taken (Weston 1968, Howard 1975, Fitzner et al. 1977, Blair 1978, Smith and Murphy 1978, Gilmer and Stewart 1983, Palmer 1988, De Smet and Conrad 1991, Atkinson 1992). Primary prey in central grasslands are ground squirrels (Spermophilus spp.), followed by eastern pocket gophers (Thomomys spp.) and white-tailed jackrabbits (Lepus townsendii) (Bechard and Schmutz 1995). Primary prey in western shrubsteppe are jackrabbits (Lepus spp.), followed by ground squirrels and pocket gophers (Smith and Murphy 1978, Bechard and Schmutz 1995). White-tailed (Cynomys leucurus) and black-tailed prairie dogs also serve as prey items (Powers and Craig 1976, MacLaren et al. 1988, Hansen 1994).

In Oregon, Janes (1985) found that the highest abundance of major prey species (whitetailed jackrabbits, Townsend's ground squirrels [Spermophilus townsendii], and northern pocket gophers [Thomomys talpoides]) occurred in native grasslands. In Utah and Idaho, black-tailed jackrabbits (Lepus californicus) were associated with sagebrush, preferring tall cover and open spaces (Westoby and Wagner 1973, Janes 1985). Black-tailed jackrabbits foraging in crested wheatgrass fields in Utah and Idaho concentrated their activity within $300 \mathrm{~m}$ of field edges (Westoby and Wagner 1973). Townsend's ground squirrels in Idaho were most abundant in grass-shrub vegetation in areas free from disturbance, especially from plowing, but also were observed in oldfields, pastures, and crested wheatgrass fields (Wakeley 1978). Northern pocket gophers in Idaho were most common in alfalfa fields (Wakeley 1978). In moderately cultivated areas of northcentral Montana, active burrow counts of Richardson's ground squirrels 
(Spermophilus richardsonii) were higher along the edges of agricultural fields than in grasslands (Zelenak and Rotella 1997).

Vulnerability of prey also is an important factor in habitat suitability, such that Ferruginous Hawks avoid dense vegetation that reduces their ability to see prey (Howard and Wolfe 1976, Wakeley 1978, Schmutz 1987). Prey vulnerability decreases where taller smallgrain crops replace shorter grasses (Houston and Bechard 1984). Intensive agricultural practices, such as annual plowing and biennial fallowing, exclude many prey species (Wakeley 1978, Houston and Bechard 1984). In Alberta, prey abundance increases as the area of cultivation increases up to $30 \%$, but abundance is reduced where agriculture is extensive, e.g., $>30 \%$ (Schmutz 1989).

\section{Area requirements:}

Estimates of home range size vary from 3.14 to $8.09 \mathrm{~km}^{2}$ in the Columbia River Basin and Great Basin regions of the western U.S. (Janes 1985). The average home range for Ferruginous Hawks was $90.3 \mathrm{~km}^{2}$ in Washington, and the variability in home range was significantly related to distance from the nest to the nearest irrigated agricultural field (Leary et al. 1998). One male that nested closest to the surrounding agricultural fields had the smallest home range, whereas another male nesting farthest from the agricultural fields had the largest home range. An area of up to $21.7 \mathrm{~km}^{2}$ may be required by one pair for hunting in Idaho (Wakeley 1978).

\section{Brown-headed Cowbird brood parasitism:}

The Ferruginous Hawk is an accidental but unsuitable host of the Brown-headed Cowbird (Molothrus ater), an obligate brood parasite (Friedmann 1929).

\section{Breeding-season phenology and site fidelity:}

Ferruginous Hawks occur on breeding areas from late February through early October (Weston 1968, Olendorff 1973, Maher 1974, Blair 1978, Smith and Murphy 1978, Gilmer and Stewart 1983, Schmutz and Fyfe 1987, Palmer 1988, Bechard and Schmutz 1995). Renesting within the same year is rare (Woffinden 1975, Palmer 1988). Territory and nest site reoccupancy is common for Ferruginous Hawks, and one of several nests within a territory may be used in alternate years (Davy 1930, Weston 1968, Olendorff 1973, Blair 1978, Smith and Murphy 1978, Palmer 1988, Roth and Marzluff 1989, Schmutz 1991b, Atkinson 1992, De Smet 1992, Houston 1995). Nest reoccupancy may be affected by nest success; in Manitoba, $52 \%$ of 71 successful nests were reused, compared to 14\% of 63 unsuccessful nests (De Smet 1992). Mate fidelity also is common. (Schmutz 1991b).

\section{Species' response to management:}

In Idaho, Ferruginous Hawks readily nested in areas burned within the past $15 \mathrm{yr}$, as well as in unburned areas (Lehman et al. 1996). In southcentral Washington, nests occurred in recently burned sagebrush/downy brome (Bromus tectorum) habitat (Leary et al. 1998).

Grazing benefits Ferruginous Hawks by reducing vegetative cover and making prey more visible (Wakeley 1978, Konrad and Gilmer 1986). Kantrud and Kologiski (1982) found highest densities of Ferruginous Hawks in heavily grazed areas in the northern Great Plains. These areas provided a combination of grazing and soil type (typic borolls) that resulted in abundant prey 
populations (Kantrud and Kologiski 1982). In South Dakota, Ferruginous Hawks preferentially placed ground nests in lightly grazed pasture or idle areas (Lokemoen and Duebbert 1976, Blair 1978, Blair and Schitoskey 1982). In Saskatchewan, preferred grassland habitat exists in large blocks of government pastures located along the Montana and Alberta borders (Houston and Bechard 1984). These blocks of habitat are the only remaining areas with stable Ferruginous Hawk populations in Saskatchewan (Houston and Bechard 1984). In Idaho and Utah, foraging Ferruginous Hawks require large pastures where Richardson's ground squirrels are abundant (Wakeley 1978, Houston and Bechard 1984). Livestock, however, can weaken nest trees by excessive rubbing or trampling (Houston 1982, Olendorff 1993). Bock et al. (1993) suggested that Ferruginous Hawks would respond negatively to grazing in shrubsteppe habitats, based on the ground cover requirements of their prey.

Conversion of grasslands to intensive cultivation has reduced the amount of preferred habitat that is available to Ferruginous Hawks and has been implicated in the population decline of the species in some areas (Schmutz 1984, Faanes and Lingle 1995). Agricultural development has restricted the species to areas of greater topographic relief or other areas unsuitable for agriculture (Stewart 1975). In Alberta, areas with $>50 \%$ cultivation were not used by Ferruginous Hawks (Schmutz 1984, 1991a). Nesting densities of Ferruginous Hawk increased as the percentage of cultivation on plots increased to 30\%, then declined (Schmutz 1989). Conversely, in Manitoba, productivity was not adversely affected by proximity of nests to agriculture; successful nests were surrounded by more cultivated land and less pasture than failed nests (De Smet and Conrad 1991). Seventy-eight percent of all nests had $>30 \%$ cultivation within $2 \mathrm{~km}$.

Petroleum development in breeding areas appears to have no negative impacts on the productivity of Ferruginous Hawks (Zelenak and Rotella 1997). The number of fledglings produced per nest in disturbed versus undisturbed areas of northcentral Montana did not differ, and no mortalities were directly attributed to oil-field activities (Van Horn 1993).

\section{Management Recommendations:}

Increase grassland area to increase Richardson's ground squirrel abundance in Canada (Houston and Bechard 1984). Improve prey habitat by providing native shrub vegetation and increasing edge (Howard and Wolfe 1976, Bechard and Schmutz 1995). If brush is chained, windrow it to provide cover for prey (Olendorff 1993). When converting land from sagebrush steppe to herbaceous grassland (e.g., to crested wheatgrass), create a mosaic of treated (chained or disced) and untreated areas (Howard and Wolfe 1976). To attract small rodents, maintain or restore sagebrush-grass rangeland, removing twoneedle pine (Pinus edulis)/Utah juniper stands (Howard and Wolfe 1976). If it is necessary to control lagomorph or rodent populations, try to lower the peaks of cyclic highs rather than completely exterminating them (Olendorff 1993).

Maintain ownership of public lands that have substantial numbers of Ferruginous Hawks (Olendorff 1993). Protect large tracts of native prairie from conversion to monotypic stands of grass or other types of agriculture (Howard and Wolfe 1976, Lardy 1980, Schmutz 1991a, Bechard and Schmutz 1995). Avoid seeding of exotic grasses and cultivating in Ferruginous Hawk habitat, where possible (Janes 1985). Leave scattered islands of shrubby vegetation in 
crested wheatgrass fields so that the islands make up a minimum of $20 \%$ of the total area (Howard and Wolfe 1976).

Do not disturb nest sites from 15 March to 15 July (Howard and Wolfe 1976, Bechard and Schmutz 1995). Close public areas near nest sites to recreation during the breeding season (Lardy 1980) and close public land to firearms where dense populations of Ferruginous Hawks are particularly susceptible to shooting (Olendorff 1993). Establish buffer zones around nest sites (Leslie 1992) and delay energy development until $45 \mathrm{~d}$ after fledging (Konrad and Gilmer 1986). White and Thurow (1985) recommended creating a buffer zone of $0.25 \mathrm{~km}$ around nest sites. Atkinson (1992) suggested that a minimum distance of $0.45 \mathrm{~km}$ be maintained from the nest. Olendorff (1993) suggested buffer zones of $0.25 \mathrm{~km}$ for brief disturbances, $0.5 \mathrm{~km}$ for intermittent activities, $0.8 \mathrm{~km}$ for prolonged activities, and $\geq 1.0 \mathrm{~km}$ for construction or similar activities. Provide information to ranchers, seismic crews, prospectors, and others to avoid disturbance to the nest (Atkinson 1992). Conduct treatments, e.g., chaining, discing, plowing, or burning, during the non-nesting season to avoid direct impacts to Ferruginous Hawks and their prey species during the reproductive season (Olendorff 1993). Generally, avoid treatments between 1 March and 1 August each year, especially during the incubation period when Ferruginous Hawks are more prone to abandon nests if disturbed. Mitigate development impacts from mining, pipeline construction, and urbanization (Bechard and Schmutz 1995).

Enhance, protect, and create nest substrates through fencing of nest trees, supporting heavy tree nests that are at risk of toppling, and building artificial nesting structures where nest sites are otherwise lacking (Olendorff 1973, Smith and Murphy 1978, Houston 1985, Bechard and Schmutz 1995, Leary et al. 1998). Other successful nest structure management techniques are to remove some of the previous year's nesting material to reduce the chance of toppling, realign the nest over a vertical axis, widen the base of the nest, reinforce the base of the nest using wire netting or other materials, move the nest to a safer location, or provide protection from predators by nailing tin sheathing around the tree base (Craig and Anderson 1979). In converting tree communities to grassland, provide nest sites by leaving individual trees, a mosaic of stands of trees, or a thin scattering of trees (Olendorff 1993). Leave poles and cross-arms of unused electrical lines for hunting perches (Olendorff 1993).

Encourage rest-rotation or deferred-rotation grazing systems (Olendorff 1993). Delay grazing to allow for the completion of incubation (Atkinson 1992). 
Table. Ferruginous Hawk habitat characteristics.

\begin{tabular}{|c|c|c|c|}
\hline Author(s) & Location(s) & Habitat(s) Studied* & Species-specific Habitat Characteristics \\
\hline Atkinson 1992 & Montana & $\begin{array}{l}\text { Shortgrass pasture, } \\
\text { shrubsteppe }\end{array}$ & $\begin{array}{l}\text { Nested on rock outcrops with an average of } 62.8 \% \text { slope } \\
\text { (nests were commonly found on the upper } 35 \% \text { of the } \\
\text { slope); habitat within } 100 \mathrm{~m} \text { of nests was primarily big } \\
\text { sagebrush (Artemisia tridentata) and grassland; nests were } \\
\text { oriented toward the south }\end{array}$ \\
\hline Bechard et al. 1990 & Washington & $\begin{array}{l}\text { Cropland, idle } \\
\text { shrubsteppe, } \\
\text { woodland }\end{array}$ & $\begin{array}{l}\text { Nested in western juniper (Juniperus occidentalis) trees } \\
\text { (isolated or near the edges of small woodlots) and on basalt } \\
\text { rock outcrops; preferred nests were }<10 \mathrm{~m} \text { from the ground } \\
\text { and southern and western exposures, some nests were in } \\
\text { moderately cultivated areas, but avoided areas of intensive } \\
\text { cultivation or high human disturbance; nests are often } \\
\text { surrounded by higher percentages of grassland, shrubland, } \\
\text { and juniper forest and low percentages of cropland }\end{array}$ \\
\hline Black 1992 & Montana & $\begin{array}{l}\text { Shortgrass pasture, } \\
\text { shrubsteppe }\end{array}$ & $\begin{array}{l}\text { Nested primarily on the ground in grassland-dominated areas } \\
\text { with rolling topography ( }>10 \% \text { slope); ground nests were } \\
\text { located either on the top of a small rise or on slopes ranging } \\
\text { from } 10 \text { to } 50 \% \text {; the area immediately surrounding nest sites } \\
\text { was characterized by }<30 \% \text { vegetative cover and vegetation } \\
<15.24 \mathrm{~cm} \text { in height; the mean height of ground nests below } \\
\text { the highest surrounding topographic feature was } 10 \mathrm{~m} \text {; the } \\
\text { mean height of ground nest sites above the valley floor was } \\
10.4 \mathrm{~m} \text {, so that nests were placed at mid-elevation within the } \\
\text { immediate topography; avoided cropland and areas with } \\
\text { dense, tall sagebrush (Artemisia) }\end{array}$ \\
\hline $\begin{array}{l}\text { Blair 1978, } \\
\text { Blair and Schitoskey }\end{array}$ & South Dakota & $\begin{array}{l}\text { Cropland, idle mixed- } \\
\text { grass, mixed-grass }\end{array}$ & $\begin{array}{l}\text { Nested on mud buttes in unbroken, ungrazed, or lightly } \\
\text { grazed prairie or badland areas surrounded by prairie; }\end{array}$ \\
\hline
\end{tabular}




\begin{tabular}{|c|c|c|c|}
\hline 1982 & & pasture, tame pasture & $\begin{array}{l}\text { avoided areas used for small-grain farming. The probability } \\
\text { of fledging young was } 11.4 \% \text { greater in more remote nests } \\
\text { than in nests within } 2.47 \mathrm{~km} \text { of occupied buildings; } \\
\text { fledglings used areas of recently cut native hay; mean height } \\
\text { of nests (on buttes or hills) above the surrounding prairie } \\
\text { was }<10 \mathrm{~m} \text {, and nests were oriented toward the south and } \\
\text { west, providing access to prevailing winds from the south } \\
\text { and west }\end{array}$ \\
\hline Davy 1930 & North Dakota & Idle mixed-grass & $\begin{array}{l}\text { Nested in tall trees, low bushes, straw stacks, stone piles, } \\
\text { and on the ground; nested in willow (Salix sp.), box elder } \\
\text { (Acer negundo), and poplar (Populus) }\end{array}$ \\
\hline De Smet 1992 & Manitoba & Not given & $\begin{array}{l}\text { Nested in cottonwood (Populus deltoides), box elder, } \\
\text { quaking aspen (Populus tremuloides), or nest structures; } \\
\text { nest structures consisted of wire baskets, modified nests } \\
\text { from previous years, wooden platforms, stick bases, or } \\
\text { modified raptor nests; average nesting success and number } \\
\text { of young per initiated nest were higher in cottonwood and } \\
\text { aspen trees than in other species of tree; higher nests had } \\
\text { better success and productivity: of } 59 \text { nests >8 m high, } 69 \% \\
\text { were successful compared to } 58 \% \text { of } 57 \text { nests 5-8 m high } \\
\text { and } 42 \% \text { of } 59 \text { nests <5 m high; reoccupancy of nests was } \\
\text { influenced by previous year’s nest success: } 37 \text { of } 71(52 \%) \\
\text { successful nests were reused compared to } 9 \text { of } 63(14 \%) \\
\text { unsuccessful nests }\end{array}$ \\
\hline $\begin{array}{l}\text { De Smet and Conrad } \\
1991\end{array}$ & Manitoba & $\begin{array}{l}\text { Cropland, mixed-grass } \\
\text { pasture }\end{array}$ & $\begin{array}{l}\text { Nested in quaking aspen, cottonwood, box elder, willow, } \\
\text { American elm (Ulmus americana), and green ash (Fraxinus } \\
\text { pennsylvanica), mean nest height was } 6.5 \mathrm{~m} \text {; placed nests } \\
\text { higher, shallower, and narrower than expected and on limbs } \\
\text { rather than in major forks of trees. Most nests were found in } \\
\text { isolated or scattered trees, but a few were found in dense }\end{array}$ \\
\hline
\end{tabular}




\begin{tabular}{|c|c|c|c|}
\hline & & & $\begin{array}{l}\text { aspen bluffs; } 75 \% \text { of nests were within } 0.8 \mathrm{~km} \text { of roads or } \\
\text { maintained trails. Successful nests had more cultivated land } \\
\text { and less pasture nearby than failed nests; } 78 \% \text { percent of } \\
\text { nests had }>30 \% \text { cultivation within } 2 \mathrm{~km}\end{array}$ \\
\hline Faanes and Lingle 1995 & Nebraska & $\begin{array}{l}\text { Cropland, idle mixed- } \\
\text { grass, idle shortgrass, } \\
\text { idle tallgrass, pasture, } \\
\text { sand-sage grassland, } \\
\text { tame hayland, } \\
\text { wetland, wet meadow, } \\
\text { woodland }\end{array}$ & $\begin{array}{l}\text { Preferred large blocks of native prairie; conversion of native } \\
\text { prairie to cropland negatively impacted prey and nesting } \\
\text { habitat; one nest was found in a cottonwood (Populus sp.) } \\
\text { surrounded by alfalfa (Medicago sativa) and corn }\end{array}$ \\
\hline Fitzner et al. 1977 & Washington & Shrubsteppe & $\begin{array}{l}\text { Nested in western juniper savannas and on rock outcrops; } \\
\text { placed nests 3.5-7.5 m from the ground }\end{array}$ \\
\hline Gaines 1985 & North Dakota & $\begin{array}{l}\text { Cropland, hayland, } \\
\text { mixed-grass pasture }\end{array}$ & $\begin{array}{l}\text { Preferred pasture or hayland } \leq 1.0 \mathrm{~km} \text { to occupied nests; } \\
\text { avoided nesting near cropland or within } 0.7 \mathrm{~km} \text { of human } \\
\text { habitation }\end{array}$ \\
\hline Gilmer and Stewart 1983 & North Dakota & $\begin{array}{l}\text { Cropland, hayland, } \\
\text { mixed-grass pasture }\end{array}$ & $\begin{array}{l}\text { Preferred to nest in pasture and hayland habitats; pasture and } \\
\text { hayland made up 95\% of the land around ground nests and } \\
76.5 \% \text { of the land around tree nests; pairs nesting in trees } \\
\text { accepted a wider variety of surrounding land uses; nests } \leq 0.5 \\
\text { km to an interstate highway or other well-traveled road had } \\
\text { similar nest success (at least one young was fledged) as } \\
\text { other nesting pairs; ground nests occurred in rugged, high } \\
\text { relief areas; used a variety of trees for nesting: cottonwood } \\
\text { (Populus deltoides), peachleaf willow (Salix amygdaloides), } \\
\text { box elder, green ash, and elm trees (Ulmus); nest trees were } \\
\text { commonly isolated or in clusters or rows }\end{array}$ \\
\hline Green and Morrison & Oregon & Shrubsteppe & Nests were built in short western juniper trees (mean=4.8 \\
\hline
\end{tabular}




\begin{tabular}{|c|c|c|c|}
\hline 1983 & & & $\begin{array}{l}\mathrm{m} \text { ), were }<10 \mathrm{~m} \text { from the ground (mean }=2.9 \mathrm{~m} \text { ), and had } \\
\text { large support branches (mean radius }=7.3 \mathrm{~cm} \text { ) }\end{array}$ \\
\hline $\begin{array}{l}\text { Houston and Bechard } \\
1984\end{array}$ & Saskatchewan & $\begin{array}{l}\text { Cropland, mixed-grass } \\
\text { pasture, shortgrass } \\
\text { pasture }\end{array}$ & $\begin{array}{l}\text { Large government pastures located along the Montana and } \\
\text { Alberta borders were the only remaining areas with stable } \\
\text { populations in Saskatchewan; required large pastures where } \\
\text { Richardson's ground squirrels (Spermophilus richardsonii) } \\
\text { were abundant; prey vulnerability decreased where taller } \\
\text { small-grain crops replaced shorter grasses; intensive } \\
\text { agricultural practices, such as annual plowing and biennial } \\
\text { fallowing, excluded many prey species }\end{array}$ \\
\hline Howard 1975 & Idaho, Utah & $\begin{array}{l}\text { Cropland, semidesert } \\
\text { shrubsteppe, tame } \\
\text { hayland, tame pasture }\end{array}$ & $\begin{array}{l}\text { Majority of nests occurred in Utah juniper (Juniperus } \\
\text { osteosperma) trees; productivity was higher in areas of } \\
\text { crested wheatgrass (Agropyron cristatum) interspersed with } \\
\text { desert shrub than monotypic stands of crested wheatgrass or } \\
\text { shrubland, or with greater amounts of juniper, alfalfa, and } \\
\text { cropland }\end{array}$ \\
\hline Howard and Wolfe 1976 & Idaho, Utah & $\begin{array}{l}\text { Cropland, semidesert } \\
\text { shrubsteppe, tame } \\
\text { hayland, tame pasture }\end{array}$ & $\begin{array}{l}\text { Avoided nesting in cultivated areas; Utah juniper trees were } \\
\text { important nesting sites; avoided areas of dense vegetation } \\
\text { which reduced a hawk's ability to see prey }\end{array}$ \\
\hline Janes 1985 & $\begin{array}{l}\text { California, } \\
\text { Idaho, Oregon, } \\
\text { Utah }\end{array}$ & $\begin{array}{l}\text { Cropland, semidesert } \\
\text { shrubsteppe }\end{array}$ & $\begin{array}{l}\text { Occupied both flat and elevated areas; avoided cropland and } \\
\text { cliffs; preferred native grasslands and shrubland (mean } \\
\text { percentages of grassland and shrubland in home ranges were } \\
51 \% \text { and } 31.5 \% \text {, respectively); preferred areas with zero } \\
\text { perches (mean percentage of home range with zero perches } \\
\text { was } 77.3 \% \text { ) }\end{array}$ \\
\hline Johnsgard 1979 & $\begin{array}{l}\text { Colorado, } \\
\text { Kansas, } \\
\text { Nebraska, }\end{array}$ & $\begin{array}{l}\text { Idle shortgrass, } \\
\text { mixed-grass pasture, } \\
\text { wet meadow }\end{array}$ & $\begin{array}{l}\text { Nested in grassland areas with scattered trees or clay buttes } \\
\text { and bluffs for use as nesting sites; in North Dakota, about } \\
\text { half of } 61 \text { nests were on the ground and the rest were on }\end{array}$ \\
\hline
\end{tabular}




\begin{tabular}{|c|c|c|c|}
\hline & $\begin{array}{l}\text { North Dakota, } \\
\text { Oklahoma, } \\
\text { New Mexico, } \\
\text { South Dakota, } \\
\text { Texas }\end{array}$ & & $\begin{array}{l}\text { boulders, piles of rocks, haystacks, strawstacks, and } \\
\text { miscellaneous locations; most of the ground nests were on } \\
\text { slopes near hillcrests or ridgetops; tree nests were located in } \\
\text { isolated trees or in groves; nest heights above ground } \\
\text { averaged } 8 \mathrm{~m} \text { and ranged from } 3 \text { to } 14 \mathrm{~m}\end{array}$ \\
\hline $\begin{array}{l}\text { Kantrud and Kologiski } \\
1982\end{array}$ & $\begin{array}{l}\text { Colorado, } \\
\text { Montana, } \\
\text { Nebraska, } \\
\text { North Dakota, } \\
\text { South Dakota, } \\
\text { Wyoming }\end{array}$ & $\begin{array}{l}\text { Mixed-grass pasture, } \\
\text { shortgrass pasture, } \\
\text { shrubsteppe }\end{array}$ & $\begin{array}{l}\text { Used heavily grazed areas of typic boroll soil type in the } \\
\text { northern Great Plains where Richardson's ground squirrels } \\
\text { were abundant }\end{array}$ \\
\hline Konrad and Gilmer 1986 & North Dakota & $\begin{array}{l}\text { Cropland, hayland, } \\
\text { mixed-grass pasture }\end{array}$ & Used hayfields and native pastures; avoided cultivated fields \\
\hline Lardy 1980 & Oregon & $\begin{array}{l}\text { Cropland, } \\
\text { shrubsteppe/tame } \\
\text { grassland }\end{array}$ & $\begin{array}{l}\text { Frequently built nests on cliff or ground that were } \\
\text { characterized by a lack of shrub cover }\end{array}$ \\
\hline Leary et al. 1998 & Washington & $\begin{array}{l}\text { Burned } \\
\text { shrubsteppe/tame } \\
\text { grassland, cropland, } \\
\text { tame hayland }\end{array}$ & $\begin{array}{l}\text { Foraged in alfalfa haylands and irrigated potato fields, and } \\
\text { nested in recently burned sagebrush/downy brome (Bromus } \\
\text { tectorum) habitat }\end{array}$ \\
\hline Lehman et al. 1996 & Idaho & $\begin{array}{l}\text { Idle shortgrass, idle } \\
\text { shrubsteppe }\end{array}$ & $\begin{array}{l}\text { Nested in areas burned within the past } 15 \mathrm{yr} \text {, as well as in } \\
\text { unburned areas }\end{array}$ \\
\hline Leslie 1992 & Colorado & $\begin{array}{l}\text { Cropland, idle, mixed- } \\
\text { grass pasture, } \\
\text { shortgrass pasture, } \\
\text { woodland }\end{array}$ & $\begin{array}{l}\text { Most frequently nested in lone or scattered trees in riparian } \\
\text { areas; nested in cottonwood, box elder, and Russian olive } \\
\text { (Elaeagnus angustifolia) trees; mean height of nesting tress } \\
\text { was } 10.3 \mathrm{~m} \text {; used windbreaks and abandoned fields for } \\
\text { nesting <5\% of the time; one pair nested in cropland }\end{array}$ \\
\hline
\end{tabular}




\begin{tabular}{|c|c|c|c|}
\hline $\begin{array}{l}\text { Lokemoen and Duebbert } \\
1976\end{array}$ & South Dakota & $\begin{array}{l}\text { Idle mixed-grass, } \\
\text { mixed-grass hayland, } \\
\text { mixed-grass pasture }\end{array}$ & $\begin{array}{l}\text { Ground nests were located far from human activities, on } \\
\text { elevated landforms in large grassland areas, or } \leq 1.6 \mathrm{~km} \text { to } \\
\text { idle or lightly grazed prairie; ground nests had a western } \\
\text { exposure; preferred lone trees or small, open groves over } \\
\text { woodland for tree nests }\end{array}$ \\
\hline MacLaren et al. 1988 & Wyoming & Idle shortgrass & $\begin{array}{l}\text { Nested on sandstone pillars, in trees, and on cliffs; mean } \\
\text { values for nest variables were as follows: } 34.30 \mathrm{~cm} \text { diameter } \\
\text { at breast height of nest trees, } 4.55 \mathrm{~m} \text { nest height, } 5.51 \mathrm{~m} \text { nest } \\
\text { substrate height, } 14.26^{\circ} \text { slope, } 0.34 \mathrm{~km} \text { from water, and } 0.44 \\
\text { km from a road }\end{array}$ \\
\hline Niemuth 1992 & Wyoming & $\begin{array}{l}\text { Shortgrass pasture, } \\
\text { shrubsteppe }\end{array}$ & $\begin{array}{l}\text { Nested on the cross-arms of an abandoned center-pivot } \\
\text { irrigation system and on the roof of an abandoned shed }\end{array}$ \\
\hline Olendorff 1973 & Colorado & $\begin{array}{l}\text { Cropland, idle } \\
\text { shortgrass, shortgrass } \\
\text { pasture }\end{array}$ & $\begin{array}{l}\text { Majority of nests were in grassland, only one nest was found } \\
\text { in cropland; more remote nests had higher fledging success } \\
\text { than more easily accessible nests }\end{array}$ \\
\hline Podany 1996 & Nebraska & $\begin{array}{l}\text { Cropland, mixed-grass } \\
\text { pasture, shortgrass } \\
\text { pasture }\end{array}$ & $\begin{array}{l}\text { No significant difference existed for the number of young } \\
\text { fledged in unfragmented rangeland versus a mixture of } \\
\text { rangeland and cropland }\end{array}$ \\
\hline Powers and Craig 1976 & Idaho & $\begin{array}{l}\text { Semidesert } \\
\text { shrubsteppe }\end{array}$ & $\begin{array}{l}\text { Nested in Utah juniper or on slopes of alluvial bluffs; } \\
\text { population fluctuations followed population cycles of prey }\end{array}$ \\
\hline $\begin{array}{l}\text { Ratcliffe and Murray } \\
1984\end{array}$ & Manitoba & Mixed-grass pasture & Nested in trembling aspen \\
\hline Rising 1974 & Kansas & $\begin{array}{l}\text { Cropland, shortgrass } \\
\text { pasture, woodland }\end{array}$ & $\begin{array}{l}\text { Nested in cottonwood, mulberry (Morus), and osage orange } \\
\text { trees (Maclura pomifera), or on ledges 2-3 m high }\end{array}$ \\
\hline Roth and Marzluff 1989 & Kansas & $\begin{array}{l}\text { Cropland, shortgrass } \\
\text { pasture }\end{array}$ & $\begin{array}{l}\text { Nested mostly on chalk outcroppings and the slopes of loess } \\
\text { canyons; nesting on chalk buttes, trees, and the ground was }\end{array}$ \\
\hline
\end{tabular}




\begin{tabular}{|c|c|c|c|}
\hline & & & $\begin{array}{l}\text { rare; nests were surrounded by } 50-75 \% \text { rangeland and } 25- \\
50 \% \text { cropland; } 90 \% \text { of nests were surrounded by } \geq 50 \% \\
\text { rangeland; majority of nests ( } 86 \text { of } 99 \text { ) were not in direct } \\
\text { view of black-tailed prairie dog (Cynomys ludovicianus) } \\
\text { towns, although most nest sites were } \leq 8 \text { km to prairie dog } \\
\text { towns }\end{array}$ \\
\hline Schmidt 1981 & North Dakota & $\begin{array}{l}\text { Idle mixed-grass, } \\
\text { mixed-grass pasture }\end{array}$ & $\begin{array}{l}\text { Two nests were found in black cottonwood (Populus } \\
\text { trichocarpa) trees }\end{array}$ \\
\hline Schmutz 1984 & Alberta & $\begin{array}{l}\text { Cropland, mixed-grass } \\
\text { pasture }\end{array}$ & $\begin{array}{l}\text { Preferred trees for nesting; avoided nesting within } 0.5 \mathrm{~km} \text { of } \\
\text { a farmyard and in areas of }>50 \% \text { cultivation }\end{array}$ \\
\hline Schmutz 1987 & Alberta & $\begin{array}{l}\text { Cropland, mixed-grass } \\
\text { pasture }\end{array}$ & $\begin{array}{l}\text { Preferred arid grasslands, which provided nest sites with } \\
\text { greater visibility and opportunities to hunt prey; avoided } \\
\text { areas of intensive agriculture or high human disturbance }\end{array}$ \\
\hline Schmutz 1989 & Alberta & $\begin{array}{l}\text { Cropland, mixed-grass } \\
\text { pasture, tame hayland, } \\
\text { tame pasture }\end{array}$ & $\begin{array}{l}\text { Nesting densities in Alberta increased as the percentage of } \\
\text { cultivation on plots increased to } 30 \% \text {, then nesting densities } \\
\text { declined; moderately cultivated areas ( } 11-30 \% \text { of } 4,100 \text {-ha } \\
\text { plots), had higher nesting densities than grassland areas with } \\
0-11 \% \text { cultivation }\end{array}$ \\
\hline Schmutz 1991a & Alberta & $\begin{array}{l}\text { Cropland, mixed-grass } \\
\text { prairie }\end{array}$ & $\begin{array}{l}\text { Nested in areas with few cultivated fields, presumably } \\
\text { because of prey availability; avoided parkland habitat }\end{array}$ \\
\hline Smith and Murphy 1978 & Utah & $\begin{array}{l}\text { Semidesert } \\
\text { shrubsteppe }\end{array}$ & $\begin{array}{l}\text { Preferred nesting in trees over the ground or ledges; Utah } \\
\text { juniper was the tree species most used for nesting }\end{array}$ \\
\hline Smith et al. 1981 & Utah & $\begin{array}{l}\text { Semidesert } \\
\text { shrubsteppe }\end{array}$ & $\begin{array}{l}\text { Density and productivity were closely correlated with cycles } \\
\text { of prey abundance }\end{array}$ \\
\hline Stewart 1975 & North Dakota & Mixed-grass prairie & $\begin{array}{l}\text { Preferred extensive areas of mixed-grass prairie; placed } \\
\text { nests on the ground, in trees, and on rock piles and hay bales }\end{array}$ \\
\hline
\end{tabular}




\begin{tabular}{|l|l|l|l|}
\hline Wakeley 1978 & Idaho & $\begin{array}{l}\text { Cropland, idle tame, } \\
\text { semidesert } \\
\text { shrubsteppe, tame } \\
\text { hayland, tame pasture }\end{array}$ & $\begin{array}{l}\text { Foraged in areas of bare ground and pasture significantly } \\
\text { more than expected by chance; may forage in alfalfa fields } \\
\text { where prey densities were presumably higher; avoided areas } \\
\text { of dense vegetation that reduce the ability to see prey; } \\
\text { grazing may benefit hunting activities by reducing } \\
\text { vegetative cover and increasing the visibility of prey }\end{array}$ \\
\hline Weston 1968 & Utah & $\begin{array}{l}\text { Semidesert } \\
\text { shrubsteppe }\end{array}$ & $\begin{array}{l}\text { Nested on sides or summits of hills, on the ground, or in } \\
\text { trees; most nests with southern or eastern exposure were on } \\
\text { the ground; nests in Utah juniper were 1.82-3.04 m high }\end{array}$ \\
\hline Woffinden 1975 & Utah & $\begin{array}{l}\text { Semidesert } \\
\text { shrubsteppe }\end{array}$ & $\begin{array}{l}\text { Nested in Utah juniper trees and on rock outcrops; majority } \\
\text { of nests are on slopes; nest trees are short (1.2-4.9 m in } \\
\text { height) and placed near cover that is suitable for black-tailed } \\
\text { jackrabbits (Lepus californicus); nest on slopes ranging from } \\
\text { 15 to 80 } \text { (mean of 42.5 })\end{array}$ \\
\hline $\begin{array}{l}\text { Woffinden and Murphy } \\
1983\end{array}$ & Idaho & $\begin{array}{l}\text { Semidesert } \\
\text { shrubsteppe }\end{array}$ & $\begin{array}{l}\text { Preferred to nest in lone or peripheral trees; also nested on } \\
\text { rock outcrops and the ground; mean nest tree height was <10 } \\
\text { m }\end{array}$ \\
\hline $\begin{array}{l}\text { Zelenak and Rotella } \\
1997\end{array}$ & Montana & $\begin{array}{l}\text { Cropland, shortgrass } \\
\text { pasture }\end{array}$ & $\begin{array}{l}\text { Nested mainly on cliffs, but also on the ground, rock } \\
\text { outcroppings, and grain bins; nests closer to cultivated fields } \\
\text { may be more successful because of higher densities of prey } \\
\text { associated with edge habitats }\end{array}$ \\
\hline
\end{tabular}

*In an effort to standardize terminology among studies, various descriptors were used to denote the management or type of habitat. "Idle" used as a modifier (e.g., idle tallgrass) denotes undisturbed or unmanaged (e.g., not burned, mowed, or grazed) areas. "Idle" by itself denotes unmanaged areas in which the plant species were not mentioned. Examples of "idle" habitats include weedy or fallow areas (e.g., oldfields), fencerows, grassed waterways, terraces, ditches, and road rights-of-way. "Tame" denotes introduced plant species (e.g., smooth brome [Bromus inermis]) that are not native to North American prairies. "Hayland" refers to any habitat that was mowed, regardless of whether the resulting cut vegetation was removed. "Burned" includes habitats that were burned intentionally or accidentally or those burned by natural forces (e.g., lightning). In situations where there are two or more descriptors (e.g., idle tame hayland), the first descriptor modifies the following descriptors. For example, idle tame hayland is habitat that is usually mowed annually but happened to be undisturbed during the year of the study. 


\section{LITERATURE CITED}

Atkinson, E. C. 1992. Ferruginous hawk (Buteo regalis) inventories on the Dillon Resource Area of southwest Montana: 1992. Montana Natural Heritage Program, Helena, Montana. 34 pages.

Bechard, M. J., R. L. Knight, D. G. Smith, and R. E. Fitzner. 1990. Nest sites and habitats of sympatric hawks (Buteo spp.) in Washington. Journal of Field Ornithology 61:159-170.

Bechard, M. J., and J. K. Schmutz. 1995. Ferruginous Hawk (Buteo regalis). In A. Poole and F. Gill, editors. The birds of North America, No. 172. The Academy of Natural Sciences, Philadelphia, Pennsylvania; The American Ornithologists' Union, Washington, D.C.

Black, A. 1992. Ferruginous Hawk reproduction and habitat survey. Northern Rockies Conservation Cooperative, Jackson, Wyoming. 30 pages.

Blair, C. L. 1978. Breeding biology and prey selection of Ferruginous Hawks in northwestern South Dakota. M.S. thesis. South Dakota State University, Brookings, South Dakota. 60 pages.

Blair, C. L., and F. Schitoskey Jr. 1982. Breeding biology and diet of the Ferruginous Hawk in South Dakota. Wilson Bulletin 94:46-54.

Bock, C. E., V. A. Saab, T. D. Rich, and D. S. Dobkin. 1993. Effects of livestock grazing on Neotropical migratory landbirds western North America. Pages 296-309 in D. M. Finch and P. W. Stangel, editors. Status and management of Neotropical migratory birds. U.S.D.A. Forest Service, General Technical Report RM-229.

Craig, G. R., and W. C. Anderson. 1979. Ferruginous Hawk nesting studies. Pages 111-120 in Game Research Report, Colorado Division of Wildlife, Denver, Colorado.

Davy, G. L. 1930. Nesting of the Ferruginous Roughleg Hawk in northern North Dakota. Oologist 47:14-18.

De Smet, K. D. 1992. Manitoba's threatened and endangered grassland birds: 1991 update and five-year summary. Manuscript report 92-03, Manitoba Natural Resources, Winnipeg, Manitoba. 77 pages.

De Smet, K. D., and M. P. Conrad. 1991. Status, habitat requirements, and adaptations of Ferruginous Hawks in Manitoba. Pages 219-221 in G. L. Holroyd, G. Burns, and H. C. Smith, editors. Proceedings of the second endangered species and prairie conservation workshop. Natural History Occasional Paper 15. Provincial Museum of Alberta, Edmonton, Alberta. 
Faanes, C. A., and G. R. Lingle. 1995. Breeding birds of the Platte River Valley of Nebraska. Jamestown, ND: Northern Prairie Wildlife Research Center home page. http://www.npwrc.usgs.gov/resource/distr/birds/platte/platte.htm (Version 16JUL97).

Fitzner, R. E., D. Berry, L. L. Boyd, and C. A. Reick. 1977. Nesting of Ferruginous Hawks (Buteo regalis) in Washington, 1974-75. Condor 79:245-249.

Friedmann, H. 1929. The cowbirds: a study in the biology of social parasitism. Thomas Books, Springfield, Illinois. 421 pages.

Friedmann, H. 1963. Host relations of the parasitic cowbirds. U.S. National Museum Bulletin 233:1-276.

Gaines, R. C. 1985. Nest site selection, habitat utilization, and breeding biology of the Ferruginous Hawk in central North Dakota. M.S. thesis. North Dakota State University, Fargo, North Dakota. 32 pages.

Gilmer, D. S., and R. E. Stewart. 1983. Ferruginous Hawk populations and habitat use in North Dakota. Journal of Wildlife Management 47:146-157.

Green, G. A., and M. L. Morrison. 1983. Nest-site selection of sympatric Ferruginous and Swainson's hawks. Murrelet 64:20-22.

Hansen, R. W. 1994. Raptor use of the Idaho National Engineering Laboratory. M.S. thesis. South Dakota State University, Brookings, South Dakota. 141 pages.

Houston, C. S. 1982. Artificial nesting platforms for Ferruginous Hawks. Blue Jay 40:208-213.

Houston, C. S. 1985. Ferruginous Hawk nest platforms--progress report. Blue Jay 43:243-246.

Houston, C. S. 1995. Thirty-two consecutive years of reproductive success at a Ferruginous Hawk nest. Journal of Raptor Research 29:282-283.

Houston, S. C., and M. J. Bechard. 1984. Decline of the Ferruginous Hawk in Saskatchewan. American Birds 38:166-170.

Howard, R. P. 1975. Breeding ecology of the Ferruginous Hawk in northern Utah and southern Idaho. M.S. thesis. Utah State University, Logan, Utah. 43 pages.

Howard, R. P., and M. L. Wolfe. 1976. Range improvement practices and Ferruginous Hawks. Journal of Range Management 29:33-37.

Janes, S. W. 1985. Habitat selection in raptorial birds. Pages 159-188 in M. L. Cody, editor. Habitat selection in birds. Academic Press, New York, New York. 
Johnsgard, P. A. 1979. Birds of the Great Plains. University of Nebraska Press, Lincoln, Nebraska. 539 pages.

Kantrud, H. A., and R. L. Kologiski. 1982. Effects of soils and grazing on breeding birds of uncultivated upland grasslands of the northern Great Plains. U.S. Fish and Wildlife Service, Wildlife Research Report 15.

Konrad, P. M., and D. S. Gilmer. 1986. Post fledging behavior of Ferruginous Hawks in North Dakota. Raptor Research 20:35-39.

Lardy, M. E. 1980. Raptor inventory and Ferruginous Hawk biology in southeastern Oregon. M.S. thesis. University of Idaho, Moscow, Idaho. 52 pages.

Leary, A. W., R. Mazaika, and M. J. Bechard. 1998. Factors affecting the size of Ferruginous Hawk home ranges. Wilson Bulletin 110:198-205.

Lehman, R. N., L. B. Carpenter, M. N. Kochert, and K. Steenhof. 1996. Effects of fire and habitat alterations on Ferruginous Hawks. Abstracts of the 114th Stated Meeting of the American Ornithologists' Union and 1996 Annual Meeting of the Raptor Research Foundation. Boise, Idaho.

Leslie, D. G. 1992. Population status, habitat and nest-site characteristics of a raptor community in eastern Colorado. M.S. thesis. Colorado State University, Fort Collins, Colorado. 45 pages.

Lokemoen, J. T., and H. F. Duebbert. 1976. Ferruginous Hawk nesting ecology and raptor populations in northern South Dakota. Condor 78:464-470.

MacLaren, P. A., S. H. Anderson, and D. E. Runde. 1988. Food habits and nest characteristics of breeding raptors in southwestern Wyoming. Great Basin Naturalist 48:548-553.

Maher, W. J. 1974. Matador Project: Birds II. Avifauna of the Matador area. Canadian Committee for the International Biological Programme, Matador Project, Technical Report 58. University of Saskatchewan, Saskatoon, Saskatchewan. 31 pages.

National Geographic Society. 1987. Field guide to the birds of North America, second edition. National Geographic Society, Washington, D.C. 464 pages.

Niemuth, N. 1992. Use of man-made structures by nesting Ferruginous Hawks in Wyoming. Prairie Naturalist 24:43.

Olendorff, R. R. 1973. The ecology of the nesting birds of prey of northeastern Colorado. U.S. International Biological Program, Grassland Biome Technical Report 211. Colorado State University, Fort Collins, Colorado. 233 pages. 
Olendorff, R. R. 1993. Status, biology, and management of Ferruginous Hawks: a review. Raptor Research and Technical Assistance Center, Special Report. U.S. Department of the Interior, Bureau of Land Management, Boise, Idaho. 84 pages.

Palmer, R. S. 1988. Ferruginous Hawk. Pages 135-151 in Handbook of North American birds, volume 5. Yale University Press, New Haven, Connecticut.

Podany, M. B. 1996. Nest placement of the Ferruginous Hawk Buteo regalis in northwestern Nebraska. M.A. thesis. University of Nebraska, Omaha, Nebraska. 26 pages.

Powers, L. R., and T. H. Craig. 1976. Status of nesting Ferruginous Hawks in the Little Lost River Valley and vicinity, southeastern Idaho. Murrelet 57:46-47.

Ratcliffe, B. D., and J. L. Murray. 1984. Recent successful nesting of Ferruginous Hawk in Manitoba. Blue Jay 42:215-218.

Rising, J. D. 1974. The status and faunal affinities of the summer birds of western Kansas. University of Kansas Science Bulletin 50:347-388.

Rolfe, E. S. 1896. Nesting of the Ferruginous Rough-leg. Osprey 1:8-10.

Roth, S. D., Jr., and J. M. Marzluff. 1989. Nest placement and productivity of Ferruginous Hawks in western Kansas. Transactions of the Kansas Academy of Science 92:132-148.

Schmidt, R. 1981. Ferruginous Hawk breeding documented in Sargent County, North Dakota. Prairie Naturalist 13:32.

Schmutz, J. K. 1984. Ferruginous and Swainson's hawk abundance and distribution in relation to land use in southeastern Alberta. Journal of Wildlife Management 48:1180-1187.

Schmutz, J. K. 1987. The effect of agriculture on Ferruginous and Swainson's hawks. Journal of Range Management 40:438-440.

Schmutz, J. K. 1989. Hawk occupancy of disturbed grasslands in relation to models of habitat selection. Condor 91:362-371.

Schmutz, J. K. 1991a. Population dynamics of Ferruginous Hawks in Alberta. Pages 212-214 in G. L. Holroyd, G. Burns, and H. C. Smith, editors. Proceedings of the second endangered species and prairie conservation workshop. Natural History Occasional Paper 15. Provincial Museum of Alberta, Edmonton, Alberta.

Schmutz, J. K. 1991b. Age-related differences in reproductive success among Ferruginous and Swainson's hawks in Alberta. Journal of Raptor Research 25:160. 
Schmutz, J. K., and R. W. Fyfe. 1987. Migration and mortality of Alberta Ferruginous Hawks. Condor 89:169-174.

Schmutz, J. K., and D. J. Hungle. 1989. Population of Ferruginous and Swainson's hawks increase in synchrony with ground squirrels. Canadian Journal of Zoology 67:25962601.

Smith, D. G., and J. R. Murphy. 1978. Biology of the Ferruginous Hawk in central Utah. Sociobiology 3:79-98.

Smith, D. G., J. R. Murphy, and N. D. Woffinden. 1981. Relationships between jackrabbit abundance and Ferruginous Hawk reproduction. Condor 83:52-56.

Stewart, R. E. 1975. Breeding birds of North Dakota. Tri-College Center for Environmental Studies, Fargo, North Dakota. 295 pages.

Van Horn, R. C. 1993. A summary of reproductive success and mortality in a disturbed Ferruginous Hawk (Buteo regalis) population in northcentral Montana. Journal of Raptor Research 27:94.

Wakeley, J. S. 1978. Factors affecting the use of hunting sites by Ferruginous Hawks. Condor 80:316-326.

Westoby, M., and F. H. Wagner. 1973. Use of a crested wheatgrass seeding by black-tailed jackrabbits. Journal of Range Management 26:349-352.

Weston, J. B. 1968. Nesting ecology of the Ferruginous Hawk, Buteo regalis. Brigham Young University Science Bulletin 10:25-36.

White, C. M., and T. L. Thurow. 1985. Reproduction of Ferruginous Hawks exposed to controlled disturbance. Condor 87:14-22.

Woffinden, N. D. 1975. Ecology of the Ferruginous Hawk (Buteo regalis) in central Utah: population dynamics and nest site selection. M.S. thesis. Brigham Young University, Provo, Utah. 102 pages.

Woffinden, N. D., and J. R. Murphy. 1983. Ferruginous Hawk nest site selection. Journal of Wildlife Management 47:216-219.

Zelenak, J. R., and J. J. Rotella. 1997. Nest success and productivity of Ferruginous Hawks in northern Montana. Canadian Journal of Zoology 75:1035-1041. 